\title{
Melittin: a venom-derived peptide with promising anti-viral properties
}

\author{
Hamed Memariani ${ }^{1} \cdot$ Mojtaba Memariani ${ }^{1}\left[\right.$ [ $\cdot$ Hamideh Moravvej $^{1} \cdot$ Mohammad Shahidi-Dadras $^{1}$
}

Received: 22 May 2019 / Accepted: 8 August 2019 / Published online: 17 August 2019

(C) Springer-Verlag GmbH Germany, part of Springer Nature 2019

\begin{abstract}
Despite tremendous advances in the development of anti-viral therapeutics, viral infections remain a chief culprit accounting for ongoing morbidity and mortality worldwide. Natural products, in particular animal venoms, embody a veritable cornucopia of exotic constituents, suggesting an immensurable source of anti-infective drugs. In this context, melittin, the principal constituent in the venom of the European honeybee Apis mellifera, has been demonstrated to exert anti-cancer, anti-inflammatory, antidiabetic, anti-infective, and adjuvant properties. To our knowledge, there is no review appertaining to effects of melittin against viruses, prompting us to synopsize experimental investigations on its anti-viral activity throughout the past decades. Accumulating evidence indicates that melittin curbs infectivity of a diverse array of viruses including coxsackievirus, enterovirus, influenza A viruses, human immunodeficiency virus (HIV), herpes simplex virus (HSV), Junín virus (JV), respiratory syncytial virus (RSV), vesicular stomatitis virus (VSV), and tobacco mosaic virus (TMV). However, medication safety, different routes of administrations, and molecular mechanisms behind the anti-viral activity of melittin should be scrutinized in future studies.
\end{abstract}

Keywords Venom $\cdot$ Bee $\cdot$ Melittin $\cdot$ Anti-viral activity $\cdot$ Drug

\section{Introduction}

Viruses virtually parasitize every living creature on planet earth, from animals and plants to bacteria and archaea. Human beings have been also afflicted by these non-living entities throughout history. Some viral diseases such as acquired immune deficiency syndrome (AIDS), Ebola hemorrhagic fever, hepatitis $\mathrm{B}$ and $\mathrm{C}$, influenza, and rabies still continue to evoke inordinate fear in societies [1]. For instance, the "Spanish flu" pandemic, which swept around the globe in 1918, claimed the lives of more people than perished in World War I [2]. The World Health Organization (WHO) estimates that 35 million individuals have succumbed to AIDSrelated illnesses since the beginning of the human immunodeficiency virus (HIV) epidemic in the early 1980s. As of 2017, nearly 36.9 million people are living with HIV worldwide [3].

Mojtaba Memariani

memaryani@gmail.com

1 Skin Research Center, Shahid Beheshti University of Medical Sciences, Tehran, Iran
Over the past half-century, tremendous efforts have been devoted to develop anti-viral drugs. However, this process is time-consuming, exorbitantly expensive, and tediously meticulous [4]. These problems are even further exasperated when mutations in a viral genome give rise to drug resistance [5]. All these facts have impelled researchers to discover unique biochemical compounds for the treatment of viral diseases. In this respect, natural products embody a miscellaneous array of exotic constituents, propounding an immensurable source of anti-infective drugs [6].

Some animals such as snake, scorpions, spiders, and bees produce poisonous secretions termed venoms to kill/ incapacitate preys or defend against predators. Regardless of their detrimental effects, animal venoms have long held a fascination for humankind owing to their pharmacologically active components including enzymes and peptides [7, 8]. In this context, therapeutic properties of venoms for treating neurologic and cardiovascular illnesses, cancer, atopic dermatitis, diabetes, and gastrointestinal maladies have been documented since medieval times [9]. Venomderived peptides have recently provoked great attention among newly enthused researchers, since they are not only selective and potent but also relatively innocuous as therapeutics $[9,10]$. Indeed, these features together with infinite 
biodiversity of venom-derived peptides may revitalize flagging drug development programs.

Heretofore, six medications derived from venom peptides have been approved by the US Food and Drug Administration (FDA) for clinical use: captopril (from snake, Bothrops jararaca; 1981), eptifibatide (from snake, Sistrurus miliarius barbouri; 1998), tirofiban (from snake, Echis carinatus; 1999), bivalirudin (from medicinal leech, Hirudo medicinalis; 2000), ziconitide (from cone snail, Conus magus; 2004), and exenatide (from lizard, Heloderma suspectum; 2005) are used for the treatment of hypertension, acute coronary syndromes, acute coronary syndromes, coagulation during surgery, chronic pain, and diabetes mellitus type 2, respectively $[9,11-16]$. At the time of writing this article, several venom-derived peptides are in clinical trials or preclinical development for curing a vast array of maladies [17].

Melittin is the principal constituent in the venom of the European honeybee Apis mellifera [18]. It is an amphipathic hexacosapeptide $\left(\mathrm{NH}_{2}\right.$-Gly-Ile-Gly-Ala-Val-Leu-Lys-ValLeu-Thr-Thr-Gly-Leu-Pro-Ala-Leu-Ile-Ser-Trp-Ile-Lys-ArgLys-Arg-Gln- $\mathrm{CONH}_{2}$ ) in which the $\mathrm{N}$ - and C-terminal regions are predominantly hydrophobic and hydrophilic, respectively $[19,20]$. This uneven distribution of polar and non-polar amino acid residues gives the melittin amphipathic structure when it is folded into an $\alpha$-helical configuration [21]. Melittin is composed of two $\alpha$-helices connected through a flexible segment [22]. Tetrameric melittin is predominant at concentrations found in the venom sac of the honeybee, but changes in peptide concentration and ionic strength result in tetramer to monomer dissociation [23, 24]. Melittin interacts with cell membranes and induces pore formation at micromolar concentrations, thereby disturbing membrane function and triggering cell lysis $[25,26]$.

In spite of some concerns over cytotoxic properties of melittin, there is a mounting body of evidence on its therapeutic values. Melittin has been shown to exert anti-cancer [27], anti-inflammatory [28], anti-diabetic [29], anti-microbial [30], anti-biofilm [24], and adjuvant [31] properties. Since the late 1970s, praiseworthy endeavors have been devoted to ascertain the anti-viral action of melittin in vitro and in vivo. To the authors' knowledge, there is no review appertaining to effects of melittin against viruses, prompting us to synopsize experimental investigations on its anti-viral activity throughout the past decades.

\section{In vitro studies}

Cell culture models are convenient and cost-effective tools to study the molecular mechanisms of viral life cycles as well as preliminary toxicological screening of drug candidates. Thus far, many investigations have been conducted to measure efficacy of melittin against diverse viral species, which are recapitulated in Tables 1 and 2. For the reader's convenience, we categorized these studies based on viral families.

\section{Arenaviridae}

The family Arenaviridae encompasses enveloped viruses with two single stranded, ambisense RNA molecules, and is usually associated with rodent-transmitted infections in human beings $[45,46]$. The family comprises three newly separated genera including Mammarenavirus, Reptarenavirus, and Hartmanivirus. Both Reptarenavirus and Hartmanivirus infect reptilian hosts, whereas Mammarenavirus infects mammalian hosts [47]. On the basis of serological cross-reactions, genetic, and geographic relationships, the genus Mammarenavirus is further subdivided into two major serogroups: The New World and the Old World [45, 47]. Noticeably, some Old World (Lassa and Lujo) and New World (Chapare, Guanarito, Junín, Machupo, and Sabia) arenaviruses are responsible for viral hemorrhagic fever, one of the most devastating emergent human diseases, with a fatality rate of $15-30 \%$ in untreated cases [48, 49]. For instance, Junín virus (JV) causes Argentine hemorrhagic fever, a severe viral illness endemic to the humid pampas of Argentina, with roughly five million people at risk [50]. Though ribavirin is the only approved anti-viral agent for treating arenaviruses in the USA; however, it exhibits undesirable secondary reactions $[32,51]$. Thus, there is exigency to develop efficient therapeutics against arenaviruses.

Melittin has been shown to cripple JV multiplication at non-toxic concentration ranges $(0.5-3 \mu \mathrm{M})$ in vitro [32]. Surprisingly, $3 \mu \mathrm{M}$ of melittin was enough to achieve a $99 \%$ reduction of JV infectivity (Table 1). Melittin concentration required to decrease virus yield by $50 \%$, known as $\mathrm{EC}_{50}$, was $0.86 \mu \mathrm{M}$ for JV (Table 2). Based on 3-(4,5-dimethylthiazol-2yl)-2,5-diphenyl tetrazolium bromide (MTT) assay, concentration of melittin needed to lessen cell viability by $50 \%$ $\left(\mathrm{CC}_{50}\right)$ was $8.51 \mu \mathrm{M}$. Besides, selectivity index $\left(\mathrm{CC}_{50} / \mathrm{EC}_{50}\right)$ of melittin was 9.89 , suggesting that it can serve as a conceivable drug for anti-viral therapy against JV [32].

\section{Flaviviridae}

The Flaviviridae is a family of arthropod-borne, enveloped viruses with a single-strand RNA of positive polarity, and currently has four genera, namely Flavivirus, Pestivirus, Hepacivirus, and Pegivirus. They frequently infect mammals and birds, causing wide range of diseases such as hepatitis, hemorrhagic fever, fatal mucosal disease, and neurological illnesses [52]. Some notable examples of the family are hepatitis $\mathrm{C}$ virus, yellow fever virus, West Nile virus, dengue virus, Japanese encephalitis virus, and Zika virus, representing 
Table 1 In vitro anti-viral effects of melittin

\begin{tabular}{|c|c|c|c|}
\hline Family/virus (strain) & Methods & Results & References \\
\hline \multicolumn{4}{|l|}{ Arenaviridae } \\
\hline Junín virus $\left(\mathrm{IV}_{4454}\right)$ & $\begin{array}{l}\text { Virucidal assay and viral } \\
\text { yield inhibition }\end{array}$ & $\begin{array}{l}\text { Melittin hampered multiplication of } \\
\text { Junín virus in Vero cells infected at a } \\
\text { multiplicity of infection (MOI) of } 0.1 \text {. }\end{array}$ & {$[32]$} \\
\hline \multicolumn{4}{|l|}{ Flaviviridae } \\
\hline Bovine viral diarrhea virus (NADL) & $\begin{array}{l}\text { Treatment of cells with melittin } \\
\text { (before and after viral infection) }\end{array}$ & $\begin{array}{l}\text { Melittin was failed to reduce viral particles, } \\
\text { though addition of apamin potentiated } \\
\text { its anti-viral activity. }\end{array}$ & {$[33]$} \\
\hline \multicolumn{4}{|l|}{ Herpesviridae } \\
\hline $\begin{array}{l}\mathrm{HSV}-1 \text { (MP, syn20, FFV3, tsB5, } \\
\text { and } a m b \text { 1511-7) }\end{array}$ & $\begin{array}{l}\text { Phase-contrast microscopy (evaluating } \\
\text { cell fusion and plaque morphology), } \\
\text { viral yield inhibition, adsorption and } \\
\text { penetration assays }\end{array}$ & $\begin{array}{l}\text { Melittin }(0.5 \mu \mathrm{M}) \text { impeded HSV-1-induced } \\
\text { cell fusion in glycoprotein K mutants, } \\
\text { but not glycoprotein B mutants. It was } \\
\text { also effective in inhibiting HSV-1 } \\
\text { adsorption and penetration. }\end{array}$ & [34] \\
\hline $\begin{array}{l}\text { HSV-1 M (ATCC VR-539) } \\
\text { and HSV-2 G (ATCC VR-734) }\end{array}$ & Virucidal assay & $\begin{array}{l}\text { Melittin completely inactivated } \\
\text { HSV-1 M and HSV-2 G. }\end{array}$ & {$[35]$} \\
\hline HSV-1 (F) and HSV-2 (G) & Virucidal assay and viral yield inhibition & $\begin{array}{l}\text { Melittin }(0.5-3 \mu \mathrm{M}) \text { inhibited infectivity } \\
\text { of both HSV-1 and HSV- } 2 \text {. }\end{array}$ & {$[32]$} \\
\hline GFP-fused HSV & $\begin{array}{l}\text { Viral yield inhibition and analysis } \\
\text { of GFP expression }\end{array}$ & $\begin{array}{l}\text { Compared to untreated groups, melittin } \\
\text { treatment }(2 \mu \mathrm{g} / \mathrm{mL}) \text { led to a } 16 \text {-fold } \\
\text { reduction in viral titers and a pronounced } \\
\text { decrease in GFP expression in infected cells. }\end{array}$ & {$[36]$} \\
\hline BoHV-1 (Los Angeles) & $\begin{array}{l}\text { Treatment of cells with melittin } \\
\text { (before and after viral infection) } \\
\text { and virucidal kinetics }\end{array}$ & $\begin{array}{l}\text { Melittin }(2 \mu \mathrm{g} / \mathrm{mL}) \text { exhibited potent anti-viral } \\
\text { effects on BoHV-1. Melittin }(25 \mu \mathrm{g} / \mathrm{mL}) \\
\text { required } 2 \text { and } 4 \mathrm{~h} \text { to completely wipe out } \\
\text { BoHV- } 1 \text { at } 37^{\circ} \mathrm{C} \text { and } 22{ }^{\circ} \mathrm{C} \text {, respectively. }\end{array}$ & [33] \\
\hline \multicolumn{4}{|l|}{ Orthomyxoviridae } \\
\hline GFP-fused influenza A (PR8) & $\begin{array}{l}\text { Viral yield inhibition, analysis of GFP } \\
\text { expression, virus attachment assay, } \\
\text { entry assay, and virucidal mechanism }\end{array}$ & $\begin{array}{l}\text { Compared to untreated groups, melittin } \\
(2 \mu \mathrm{g} / \mathrm{mL}) \text { reduced both viral titers } \\
\text { and GFP expression in infected cells } \\
\text { (without affecting either virus-cell } \\
\text { attachment or virus entrance into cells). }\end{array}$ & {$[36]$} \\
\hline \multicolumn{4}{|l|}{ Picornaviridae } \\
\hline EV-71 & $\begin{array}{l}\text { Viral yield inhibition, analysis of GFP } \\
\text { expression, and real-time polymerase } \\
\text { chain reaction }\end{array}$ & $\begin{array}{l}\text { Melittin reduced EV-71 infectivity and } \\
\text { cytopathic effects as well as mRNA } \\
\text { expression levels of VP1 (4-fold) } \\
\text { compared to untreated groups. }\end{array}$ & {$[36]$} \\
\hline GFP-fused coxsackievirus (H3) & $\begin{array}{l}\text { Viral yield inhibition and analysis of } \\
\text { GFP expression }\end{array}$ & $\begin{array}{l}\text { Melittin }(2 \mu \mathrm{g} / \mathrm{mL}) \text { diminished both } \\
\text { GFP expression }(1.5 \text {-fold) in infected } \\
\text { cells and virus titers ( } 5 \text {-fold) compared } \\
\text { to untreated groups. }\end{array}$ & {$[36]$} \\
\hline \multicolumn{4}{|l|}{ Pneumoviridae } \\
\hline GFP-fused RSV & $\begin{array}{l}\text { Viral yield inhibition and analysis of } \\
\text { GFP expression }\end{array}$ & $\begin{array}{l}\text { Melittin }(2 \mu \mathrm{g} / \mathrm{mL}) \text { markedly reduced } \\
\text { not only virus titers but also GFP } \\
\text { expression in infected cells compared } \\
\text { to untreated groups. }\end{array}$ & {$[36]$} \\
\hline \multicolumn{4}{|l|}{ Rhabdoviridae } \\
\hline GFP-fused VSV & $\begin{array}{l}\text { Viral yield inhibition, analysis of GFP } \\
\text { expression, and virucidal kinetics }\end{array}$ & $\begin{array}{l}\text { Melittin }(2 \mu \mathrm{g} / \mathrm{mL}) \text { rapidly }(5-30 \mathrm{~min}) \\
\text { suppressed VSV infectivity, and } \\
\text { caused substantial reduction in both } \\
\text { virus titer and GFP expression in } \\
\text { infected cells compared to untreated groups. }\end{array}$ & {$[36]$} \\
\hline VHSV & Immunostaining focus assay & $\begin{array}{l}\text { Melittin-loaded liposomes and immunoliposomes } \\
\text { inhibited VHSV-infected cell foci formation } \\
\text { and reduced the VHSV spread in cell culture. }\end{array}$ & {$[37]$} \\
\hline
\end{tabular}


Table 1 (continued)

\begin{tabular}{|c|c|c|c|}
\hline Family/virus (strain) & Methods & Results & References \\
\hline \multicolumn{4}{|l|}{ Retroviridae } \\
\hline MuLV (ATS-124) & Direct virolysis and electron microscopy & $\begin{array}{l}\text { Melittin }(50 \mu \mathrm{g}) \text { disintegrated the viral membrane, } \\
\text { resulting in complete release of reverse } \\
\text { transcriptase after } 30 \mathrm{~min} \text { of incubation at } 20^{\circ} \mathrm{C} \text {. }\end{array}$ & {$[38]$} \\
\hline RAV-2 & $\begin{array}{l}\text { Direct virolysis (permeabilization } \\
\text { of viral envelope) }\end{array}$ & $\begin{array}{l}\text { Melittin made the viral envelope permeable. } \\
\text { Compared to NP-40, melittin caused } \\
\text { less damage to viral structure, permitting } \\
\text { synthesis of full-length cDNA. }\end{array}$ & [39] \\
\hline HIV-1 (SF2) & $\begin{array}{l}\text { Direct virolysis (permeabilization } \\
\text { of viral envelope) }\end{array}$ & $\begin{array}{l}\text { Melittin }(20-100 \mu \mathrm{g} / \mathrm{mL}) \text { was exploited to } \\
\text { permeabilize HIV-1 envelope. Melittin } \\
\text { treatment led to a } 30 \% \text { higher endogenous } \\
\text { cDNA yield compared to Triton X-100. }\end{array}$ & {$[40]$} \\
\hline HIV-1 (IIIB) & $\begin{array}{l}\text { Viral yield inhibition, treatment of } \\
\text { HIV-1-infected cells with melittin, } \\
\text { and western blot analysis }\end{array}$ & $\begin{array}{l}\text { Melittin at } 0.5 \text { and } 2.5 \mu \mathrm{g} / \mathrm{mL} \text { reduced } \mathrm{HIV} \\
\text { infectivity in supernatants of KE37/1 } \\
\text { T lymphoma cells by } \leq 40 \% \text { and } 100 \%, \\
\text { respectively. Compared to untreated cells, } \\
\text { expression of a } 31 \mathrm{kDa} \text { protein was reduced } \\
\text { in melittin-treated cell extracts. }\end{array}$ & [41] \\
\hline HIV-1 (IIIB) and HIV-1 (RF) & $\begin{array}{l}\text { Treatment of infected cells with } \\
\text { melittin, quantitative RT-PCR } \\
\text { analysis, assessment of HIV LTR } \\
\text { activity, and western blot analysis }\end{array}$ & $\begin{array}{l}\text { Melittin dose-dependently inhibited virus } \\
\text { production in T lymphoma or fibroblastoid } \\
\text { cells infected with HIV-1. Melittin treatment } \\
\text { of T cells diminished levels of Gag antigen, } \\
\text { viral mRNA, and HIV LTR activity. }\end{array}$ & {$[42]$} \\
\hline $\begin{array}{l}\text { HIV-1 (NLHX) and HIV-1 } \\
\text { (NLYU2) }\end{array}$ & $\begin{array}{l}\text { Virucidal assay (measuring luciferase } \\
\text { activity) and HIV-1 capture assay } \\
\text { (measuring total amount of viral } \\
\text { protein p24 by ELISA) }\end{array}$ & $\begin{array}{l}\text { Both free melittin and melittin-loaded } \\
\text { nanoparticles reduced HIV-1 infectivity. } \\
\text { Melittin-loaded nanoparticles captured } \\
\text { more HIV-1 compared to blank nanoparticles. }\end{array}$ & {$[43]$} \\
\hline \multicolumn{4}{|l|}{ Virgaviridae } \\
\hline TMV (U1) & $\begin{array}{l}\text { Virucidal assay (determining percentage } \\
\text { of local lesions on tobacco leaves), } \\
\text { bond-shift assay, and circular } \\
\text { dichroism measurements }\end{array}$ & $\begin{array}{l}\text { Melittin diminished infectivity of TMV } \\
\text { and induced conformational changes } \\
\text { in TMV RNA. }\end{array}$ & {$[44]$} \\
\hline
\end{tabular}

BoHV-1 bovine herpesvirus type 1, ELISA enzyme-linked immunosorbent assay, EV-71 enterovirus 71, GFP-fused influenza A green fluorescent proteinfused influenza A (A/PuertoRico/8/34) (H1N1), HIV-1 human immunodeficiency virus-1, HSV-1 herpes simplex virus 1 , LTR long terminal repeat, $M u L V$ Rauscher murine leukemia virus, $R A V$-2 Rous associated virus-2, $R S V$ respiratory syncytial virus, $R T-P C R$ quantitative reverse transcriptasepolymerase chain reaction, $T M V$ tobacco mosaic virus, $V H S V$ fish viral hemorrhagic septicemia rhabdovirus, $V S V$ vesicular stomatitis virus

a severe global public health problem with major socioeconomic consequences [53].

Very recently, Picoli et al. investigated anti-viral effects of melittin on bovine viral diarrhea virus (BVDV) [33], the causative agent of bovine viral diarrhea which leads to considerable financial losses in many beefexporting countries [54]. Melittin had no satisfactory anti-viral activity against BVDV, before and after infection of Madin-Darby bovine kidney cells with the virus (multiplicity of infection; MOI $=0.1$ ). Intriguingly, combinations of melittin with bee venom-derived apamin were superior against BVDV than each agent alone, highlighting that apamin potentiates anti-BVDV efficacy of melittin [33]. Based on these findings, it is sensible to combine melittin with other available anti-viral drugs to ascertain whether the new combinations can abolish Flavivirus infectivity.

\section{Herpesviridae}

Viruses forming the family Herpesviridae contain doublestranded linear DNA encased within an icosapentahedral capsid, which is wrapped in a tegument and a lipid envelope [55]. Among more than hundred known herpes viruses, nine infect humans including herpes simplex virus 1 (HSV-1), HSV-2, varicella zoster virus (VZV), cytomegalovirus (CMV), human herpes virus (HHV)-6A, HHV-6B, HHV-7, Epstein-Barr virus (EBV), and Kaposi's sarcoma-associated herpesvirus (KSHV/HHV-8) [56]. Unquestionably, herpes simplex viruses are one of the most pervasive pathogens among humans, afflicting up to $95 \%$ of the adult population worldwide [57, 58]. Clinical manifestations range from benign and generally self-limiting forms including cold sores and genital herpes to the rare but severe and sometimes even life-menacing infections such as herpes encephalitis. Acyclovir (ACV) and 
Table 2 Anti-viral activities, cytotoxicity effects, and selectivity indices of melittin

\begin{tabular}{|c|c|c|c|c|c|}
\hline Family/virus (strain) & $\mathrm{EC}_{50} \pm \mathrm{SD}$ & Cells & $\mathrm{CC}_{50} \pm \mathrm{SD}$ & SI & References \\
\hline \multicolumn{6}{|l|}{ Arenaviridae } \\
\hline Junín virus $\left(\mathrm{IV}_{4454}\right)$ & $0.86 \mu \mathrm{M}$ & Vero & $8.51 \mu \mathrm{M}$ & 9.89 & {$[32]$} \\
\hline \multicolumn{6}{|l|}{ Flaviviridae } \\
\hline Bovine viral diarrhea virus (NADL) & ND & MDCK & $2.32 \mu \mathrm{g} / \mathrm{mL}$ & ND & {$[33]$} \\
\hline \multicolumn{6}{|l|}{ Herpesviridae } \\
\hline HSV-1 (F) & $1.35 \mu \mathrm{M}$ & Vero & $8.51 \mu \mathrm{M}$ & 6.30 & {$[32]$} \\
\hline HSV-2 (G) & $2.05 \mu \mathrm{M}$ & Vero & $8.51 \mu \mathrm{M}$ & 4.15 & {$[32]$} \\
\hline GFP-fused HSV & $0.94 \pm 0.07 \mu \mathrm{g} / \mathrm{mL}$ & Vero & $6.23 \pm 0.07 \mu \mathrm{g} / \mathrm{mL}$ & 6.62 & {$[36]$} \\
\hline \multicolumn{6}{|l|}{ Orthomyxoviridae } \\
\hline GFP-fused influenza A (PR8) & $1.15 \pm 0.09 \mu \mathrm{g} / \mathrm{mL}$ & MDCK & $7.66 \pm 0.94 \mu \mathrm{g} / \mathrm{mL}$ & 6.66 & {$[36]$} \\
\hline \multicolumn{6}{|l|}{ Picornaviridae } \\
\hline EV-71 & $0.76 \pm 0.03 \mu \mathrm{g} / \mathrm{mL}$ & $\mathrm{HeLa}$ & $4.36 \pm 0.54 \mu \mathrm{g} / \mathrm{mL}$ & 5.73 & {$[36]$} \\
\hline GFP-fused coxsakievirus (H3) & $0.99 \pm 0.09 \mu \mathrm{g} / \mathrm{mL}$ & $\mathrm{HeLa}$ & $4.36 \pm 0.54 \mu \mathrm{g} / \mathrm{mL}$ & 4.40 & {$[36]$} \\
\hline \multicolumn{6}{|l|}{ Pneumoviridae } \\
\hline GFP-fused RSV & $0.35 \pm 0.08 \mu \mathrm{g} / \mathrm{mL}$ & HEp2 & $5.02 \pm 0.17 \mu \mathrm{g} / \mathrm{mL}$ & 14.34 & {$[36]$} \\
\hline \multicolumn{6}{|l|}{ Rhabdoviridae } \\
\hline GFP-fused VSV & $1.18 \pm 0.09 \mu \mathrm{g} / \mathrm{mL}$ & Vero & $6.23 \pm 0.07 \mu \mathrm{g} / \mathrm{mL}$ & 5.27 & [36] \\
\hline \multicolumn{6}{|l|}{ Retroviridae } \\
\hline HIV-1 (NLHX) & $2.4 \mu \mathrm{M}$ & Vaginal epithelial cells (VK2) & ND & ND & {$[43]$} \\
\hline HIV-1 (NLYU2) & $3.6 \mu \mathrm{M}$ & Vaginal epithelial cells (VK2) & ND & ND & {$[43]$} \\
\hline
\end{tabular}

BoHV-1 bovine herpesvirus type $1, C C_{50}$ melittin concentration needed to lessen cell viability by $50 \%, E C_{50}$ melittin concentration required to decrease virus yield by $50 \%, E V-71$ enterovirus 71 , GFP-fused influenza A green fluorescent protein-fused influenza A (A/PuertoRico/8/34) (H1N1), HIV-1 human immunodeficiency virus-1, HSV-1 herpes simplex virus $1, N D$ not determined, $M D C K$ Madin-Darby canine kidney, $R S V$ respiratory syncytial virus, $S D$ standard deviation, $S I$ selectivity index $\left(\mathrm{CC}_{50} / \mathrm{EC}_{50}\right)$

related nucleoside analogues have been successfully employed in treating HSV infections, but the treatment should be commenced as soon as possible after onset of symptoms. Furthermore, efficiency of the current anti-HSV drugs is generally limited and gives rise to only marginal improvements in lesion healing time or episode duration [59]. For this reason, there is room for more efficacious therapies.

HSV entrance into cells occurs following fusion of viral envelope with host cell membrane. Several glycoproteins are involved in HSV-induced cell fusion [60]. It is worth mentioning that wild-type HSV-1 strains usually induce a limited amount of cell fusion, while certain HSV mutants known as syn mutants lead to extensive syncytium formation [61]. Disturbance of trans-membrane ion gradients impedes HSV-1-induced cell fusion [62]. This fact together with perturbation effects of melittin on $\mathrm{Na}^{+}, \mathrm{K}^{+}$pump [63] propelled researchers to explore whether melittin influences HSV-1-induced cell fusion [34]. Fusion of Vero cells infected with HSV strains (MP, syn20, and FFV3) harboring the $\operatorname{syn} 1$ mutation in glycoprotein $\mathrm{K}$ was inhibited in the presence of melittin $(0.5 \mu \mathrm{M})$, with no evidence of cytotoxicity toward Vero cells (Table 1). By contrast, melittin $(0.5 \mu \mathrm{M})$ failed to affect cell fusion induced by
HSV strains containing mutations in glycoprotein B $(t s \mathrm{~B} 5$ and $a m b$ 1511-7). In presence of melittin, binding of ouabain (a specific inhibitor of the $\mathrm{Na}^{+}, \mathrm{K}^{+}$ATPase) to the $\mathrm{Na}^{+}, \mathrm{K}^{+}$pump of HSV-1-infected Vero cells was drastically diminished. The peptide also reduced HSV-1 yield in Vero cells compared to untreated control. In addition, the authors found that melittin is able to obstruct HSV-1 attachment onto Vero cells in a dose-dependent manner and to hinder HSV-1 penetration into cells [34].

Melittin has been demonstrated to exert marked antiherpetic activity against HSV-1 M and HSV-2 G [35]. However, melittin at concentration of $100 \mu \mathrm{g} / \mathrm{mL}$ displayed $99.9 \pm 0.2 \%$ cytotoxicity towards ME- 180 human cervical carcinoma cells. Similarly, an extensive hemolysis (94.6\%) occurred at concentration of $80 \mu \mathrm{g} / \mathrm{mL}$ [35]. It has been also evinced that $3 \mu \mathrm{M}$ of melittin curbed in vitro infectivity of both HSV-1 and HSV-2 by $80 \%$. Incubation of Vero cell with melittin $(>5 \mu \mathrm{M})$ at $37{ }^{\circ} \mathrm{C}$ for $24 \mathrm{~h}$ resulted in cell rounding and monolayer detachment, as manifested by light microscopy [32]. Selectivity index of melittin was calculated to be 6.30 and 4.15 for HSV-1 and HSV-2, respectively (Table 2). In another major study, Uddin et al. found that melittin directly inhibits Green Fluorescent Protein (GFP)-fused HSV (EC ${ }_{50}$ of 
$0.94 \pm 0.07 \mu \mathrm{g} / \mathrm{mL}$ ) [36], which corroborates the findings of the earlier investigations $[32,34,35]$. Compared to untreated viruses, melittin treatment of GFP-HSV minimized not only GFP expression in infected cells but also viral titers (16-fold).

A new investigation [33] revealed the potential antiviral effects of melittin on bovine herpesvirus type 1 (BoHV-1, Los Angeles strain). Administration of melittin $(2 \mu \mathrm{g} / \mathrm{mL})$ on Madin-Darby bovine kidney cells before and after infection with BoHV-1 (MOI $=0.1)$ resulted in marked reduction of viral titers. In light of virucidal kinetics, complete obliteration of BoHV-1 was achieved after a 2-h incubation of the virus with $25 \mu \mathrm{g} / \mathrm{mL}$ of melittin at $37{ }^{\circ} \mathrm{C}$ [33], implying rapid anti-viral effects of melittin. Given that melittin curtails the infectivity of HSV in several ways, it is imperative to evaluate its anti-viral effectiveness against other members of Herpesviridae as well.

\section{Orthomyxoviridae}

The family Orthomyxoviridae comprises enveloped viruses with negative sense, segmented, single-stranded RNA, and includes seven genera: Influenzavirus A, Influenzavirus $B$, Influenzavirus $C$, Influenzavirus D, Isavirus, Quaranjavirus, and Thogotovirus [46, 64]. Influenza viruses are the most prominent member of this family [65]. WHO has been estimated that influenza-mediated debilitating respiratory ailments occur in 3 to 5 million people annually, of whom roughly 290,000 to 650,000 succumb to influenza-related illnesses [66]. Influenza A viruses are further subtyped on the basis of two main antigenic determinants named hemagglutinin (HA; H1-H16) and neuraminidase (NA; N1-N9) [67]. High genetic variation rates of influenza viruses due to mutation, reassortment, and/or recombination together with the lack of effective anti-influenza agents underscore the necessity of developing novel anti-viral drugs [68].

Melittin is able to mitigate infectivity of influenza A virus [36]. In this regard, $1.15 \pm 0.09 \mu \mathrm{g} / \mathrm{mL}$ of melittin was sufficient for $50 \%$ reduction in plaque-forming units (PFUs) of GFP-fused influenza A (H1N1, PR8-GFP). Furthermore, $\mathrm{CC}_{50}$ of melittin was $7.66 \pm 0.94 \mu \mathrm{g} / \mathrm{mL}$ for Madin-Darby canine kidney cells. Considering both antiviral and cytotoxic activities, selectivity index of melittin was 6.66 (Table 2), inferring that anti-influenza activity of melittin does not emanate from cytotoxic effect of the peptide [36]. In initial stages of infection, melittin $(2 \mu \mathrm{g} / \mathrm{mL})$ did not interfere with both cell attachment and entry of PR8-GFP strain. When PR8-GFP strain was co-incubated with melittin (for 30 min at $4{ }^{\circ} \mathrm{C}$ ), waning in viral mass was observed, as evaluated by velocity sedimentation ultracentrifugation and subsequent immunoblotting [36]. At $24 \mathrm{~h}$ post-infection, melittin treatment $(2 \mu \mathrm{g} / \mathrm{mL}, 30 \mathrm{~min})$ of PR8-GFP led to significant reduction in viral titers (5-fold, $P<0.01)$ and GFP expression compared to untreated PR8-
GFP. These data suggest direct effect of melittin on PR8GFP surface, prior to virus-cell attachment. Li et al. postulated that surface charge interactions between a cationic peptide from scorpion venom named Mucroporin-M1 and influenza H5N1 can diminish viral infectivity [68]. Thus, melittin may interact with phospholipid bilayer of viral envelope through electrostatic interactions and destabilize viral particles, eventually leading to virolysis.

\section{Picornaviridae}

All of the Picornaviridae members have single-stranded positive sense RNA genome with a non-enveloped icosahedral capsid [65]. As one of the largest viral families, it currently has 35 genera including 80 species. These viruses cause a wide variety of maladies involving respiratory and gastrointestinal tracts, central nervous system, heart, liver, skin, and eye [69].

One study [36] demonstrated the anti-viral effects of melittin against enterovirus 71 (EV-71), one of the chief culprits behind the hand, foot, and mouth disease, which can lead to neurological, cardiac, and respiratory complications in young children [70]. Melittin/EV-71-treated cells exhibited lower cytopathic effects (CPEs) and higher cellular viability than those of EV-71-infected cells. Furthermore, mRNA expression levels of capsid protein VP1 in melittin/EV-71-treated cells displayed a 4-fold decrement compared to EV-71infected cells (Table 1). As evidenced in Table 2, $\mathrm{EC}_{50}$ and $\mathrm{CC}_{50}$ of melittin for EV-71 and HeLa were $0.76 \pm 0.03$ and $4.36 \pm 0.54 \mu \mathrm{g} / \mathrm{mL}$, respectively, resulting in selectivity index of 5.73. These observations confirmed the inhibitory effects of melittin on either EV-71 replication or CPE induction, making the peptide an attractive candidate for prophylactic or therapeutic use against enterovirus infections [36].

Uddin et al. [36] also found that melittin suppresses infectivity of GFP-fused coxsackievirus H3 (cardiopathogenic H3 strain of coxsackievirus B3) with $\mathrm{EC}_{50}$ of $0.99 \pm 0.09 \mu \mathrm{g} / \mathrm{mL}$. Moreover, $\mathrm{CC}_{50}$ of melittin for HEp-2 cells was $4.36 \pm$ $0.54 \mu \mathrm{g} / \mathrm{mL}$. Selectivity index of melittin was also calculated to be 4.40. Co-incubation of H3-GFP (MOI =2) with $2 \mu \mathrm{g} /$ $\mathrm{mL}$ of melittin for $30 \mathrm{~min}$ at $4{ }^{\circ} \mathrm{C}$ and subsequent inoculation of the mixture to HeLa cells resulted in 5 -fold $(P<0.05)$ and 1.5 -fold $(P<0.05)$ reduction in viral titers and GFP expression, respectively, compared to H3-GFP-infected cells not subjected to melittin treatment. Indeed, these findings imply that melittin has pronounced virucidal activity against coxsackievirus at non-cytotoxic concentrations.

\section{Pneumoviridae}

The family Pneumoviridae contains enveloped viruses with single-stranded, negative-sense RNA, and has two genera, Orthopneumovirus and Metapneumovirus [65]. The genus 
Metapneumovirus has two species (Avian metapneumovirus and Human metapneumovirus), while Orthopneumovirus contains three species (Bovine respiratory syncytial virus, Human respiratory syncytial virus, and Murine pneumonia virus) [71]. Human respiratory syncytial virus (RSV) is a major etiological agent of respiratory diseases such as pneumonia and bronchiolitis, particularly in children, elderly, and immunocompromized patients [72]. Worldwide, around 33.8 million new cases of RSV-associated acute lower respiratory infection are estimated to occur in children under the ages of 5 years annually, of whom at least 3.4 million required hospitalizations [73, 74]. Despite the magnitude of RSV disease, treatment has been limited to supportive measures, bronchodilators, epinephrine, and ribavirin [75].

Melittin has the ability to extinguish RSV infectivity [36]. Compared to RSV-infected HEp-2 cells without melittin treatment, incubation of GFP-RSV with $2 \mu \mathrm{g} / \mathrm{mL}$ of melittin for $30 \mathrm{~min}$ at $4{ }^{\circ} \mathrm{C}$ and subsequent inoculation of the mixture to HEp-2 cells (MOI of 1 ) caused significant decrements in GFP expression $(P<0.01)$ and viral supernatant titers $(82$-fold, $P<$ 0.01 ) at $24 \mathrm{~h}$ post-infection (Table 1). $\mathrm{EC}_{50}$ and $\mathrm{CC}_{50}$ toward RSV-GFP and HEp-2 cells were $0.35 \pm 0.08$ and $5.02 \pm$ $0.17 \mu \mathrm{g} / \mathrm{mL}$, respectively (Table 2 ). Given that melittin displayed higher level of selectivity toward RSV over HEp-2 cells (selectivity index of 14.34), the peptide can be considered as an auspicious agent for anti-RSV therapy.

\section{Retroviridae}

Retroviruses are enveloped viruses with two copies of positive-sense RNA which use their own reverse transcriptase (RT) to generate DNA from its RNA genome [65]. Viruses belonging to Retroviridae are responsible for economically devastating diseases ranging from malignancies to immune deficiencies and neurologic disorders. HIV, which is historically related to the AIDS pandemic, is categorized under the genus Lentivirus within the family of Retroviridae. Thus far, six therapeutic classes of antiretroviral drugs are available for the management of HIV infection including entry or fusion inhibitors, nucleoside/ nucleotide analogue reverse-transcriptase inhibitors (NRTIs/NtRIs), non-nucleoside reverse transcriptase inhibitors (NNRTIs), integrase inhibitors, and protease inhibitors [76]. Although anti-retroviral combination therapy enhances life expectancy substantially, there is still no cure for AIDS. In fact, all HIV cure approaches are generally in their infancy [65].

There are several lines of evidence concerning antiretroviral activities of melittin against different retroviruses (Table 1). The first investigation on anti-viral efficacy of melittin dates back to the late 1970s, when Esser et al. appraised direct virolytic effect of melittin toward Rauscher murine leukemia virus $(\mathrm{MuLV})$. The authors demonstrated that
$50 \mu \mathrm{g}$ of melittin is enough to "peel off" the viral envelope [38]. As an alternative to non-ionic detergent NP-40, melittin can permeabilize avian retrovirus envelope for cDNA synthesis [39], confirming an earlier finding reported by Esser et al. [38]. Permeabilization of HIV-1 envelope for synthesis of cDNA is further exemplified in a study conducted by Yong et al. [40].

Melittin can also minimize production of HIV-1 in persistently HIV-1-infected KE37/1 T lymphoma cells [41]. In this context, complete reduction of viral particles in supernatants of HIV-1-infected cells was observed after applying of melittin at a non-cytotoxic concentration of $2.5 \mu \mathrm{g} / \mathrm{mL}$. Western blot analysis demonstrated the reduction of a $31 \mathrm{kDa}$ protein in melittin-treated cell extracts [41]. This protein could relate to some fragments of processed Gag/Pol precursor polyprotein or p31 integrase. Furthermore, data retrieved from C-terminal and truncated derivatives of melittin suggest that both amphipathic alpha-helical part (residues 120) and cationic amino acid residues in the C-terminal end of melittin are accounted for its anti-viral properties against HIV1 , resulting in intracellular impairment of viral protein production rather than a direct disruption of viral envelope [41].

Another survey proved the anti-HIV effectiveness of melittin at non-cytotoxic concentrations [42]. In this respect, melittin attenuated HIV-1 production in HUT78-RF (chronically HIV-1-infected T cells), HUT78 (acutely HIV-1-infected T cells), and LC5-CD4 (acutely HIV-1-infected fibroblasts) in a dose-dependent manner. In the case of melittin-treated cells, metabolic activity at the $50 \%$ infectious dose $\left(\mathrm{ID}_{50}\right)$ was higher than $85 \%$ of control cultures. Furthermore, western blot analysis indicated that levels of Gag antigen declined in KE37/1 (acutely HIV-1-infected T lymphoma cells) lysates following 9 days treatment with melittin $(1.05$ and $1.4 \mu \mathrm{M})$ compared to controls [42]. Quantitative reverse transcriptasepolymerase chain reaction (RT-PCR) results also demonstrated that melittin does not suppress expression of porphobilinogen deaminase, a cellular housekeeping gene. Interestingly, melittin suppresses HIV long terminal repeat (LTR) activity in a Tat-independent manner, indicating that melittin interferes with host cell-directed viral gene expression [42]. All the cumulative evidence indicates that dosedependent anti-HIV effect of melittin is mediated by suppressing HIV transcription and decreasing overall levels of viral gene products rather than the lysis of cellular or viral membranes.

Hood et al. reported the first proof-of-concept investigation concerning inhibition of HIV-1 infectivity by melittinloaded nanocarriers [43]. In order to quantify HIV-1 infectivity, the authors applied TZM-bl cell line, which is HeLaderived cells capable of expressing CD4, CCR5, and CXCR4. The cell line also harbors luciferase reporter gene under the control of an HIV-1 promoter [77]. After incubation of $50 \mathrm{ng}$ HIV-1 NLHX (CXCR4 tropic) or HIV-1 
NLYU2 (CCR5 tropic) strains with soluble CD4 (served as a positive control), nanoparticles, and free melittin at $37^{\circ} \mathrm{C}$, treated viruses were exploited to infect TZM-bl reporter cells for $48 \mathrm{~h}$ at $37^{\circ} \mathrm{C}$. This is followed by lysing the cells and gauging luciferase activity (as a measurement of HIV-1 infectivity). Remarkably, free melittin at concentrations greater than $6 \mu \mathrm{M}$ was able to extirpate infectivity of both NLHX and NLYU2 strains. Although $2 \mu \mathrm{M}$ of free melittin did not influenced viability of TZM-bl reporter cells, concentrations above $2 \mu \mathrm{M}$ rapidly diminished cellular viability, indicating a narrow therapeutic range of melittin. Contrary to free melittin, melittin-loaded nanoparticles had no toxicity toward vaginal keratinocytes in vitro [43]. Besides, 50\% inhibitory concentration of melittin-loaded nanoparticles were 2.4 and $3.6 \mu \mathrm{M}$ against NLHX and NLYU2 strains, respectively, with no adverse effects on reporter cell viability. Lipid-to-lipid membrane hemifusion events may facilitate melittin transportation from nanoparticle lipid monolayers to HIV-1 envelope bilayers, subsequently resulting in melittin aggregation, pore formation, and deactivation of viral packaging [43]. Simplicity of nanoparticle production, lack of melittin nanoparticles toxicity against vaginal keratinocytes, and their potential in reducing HIV-1 infectivity are striking properties of this approach for intra-vaginal prevention of HIV transmission.

\section{Rhabdoviridae}

Members of Rhabdoviridae have characteristic bullet-shaped or bacilliform membrane-enveloped particles with singlestranded, negative-sense RNA. Viruses belonging to Rhabdoviridae afflict an extremely broad range of hosts including plants, fish, mammals, reptiles, and even invertebrates [65]. Vesicular stomatitis virus (VSV) is an arthropod-borne Rhabdovirus that cause vesicular disease in cattle, horses, and swine, leading to negative economic impacts on animal husbandry $[78,79]$.

One study was performed in an attempt to appraise antiviral effects of melittin on VSV in vitro [36]. In this respect, melittin $(0.5-10 \mu \mathrm{g} / \mathrm{mL})$ was co-incubated with VSV-GFP for 30 min at $4{ }^{\circ} \mathrm{C}$, after which viral suspensions with MOI of 0.2 were inoculated to Vero cells. Melittin displayed $\mathrm{EC}_{50}$ value of $1.18 \pm 0.09 \mu \mathrm{g} / \mathrm{mL}$ against VSV-GFP, while it showed $\mathrm{CC}_{50}$ of $6.23 \pm 0.07 \mu \mathrm{g} / \mathrm{mL}$ toward Vero cells, resulting in selectivity index of 5.27 [36]. Incubation of melittin $(2 \mu \mathrm{g} /$ $\mathrm{mL}$ ) with VSV-GFP at $4{ }^{\circ} \mathrm{C}$ for $30 \mathrm{~min}$ and subsequent inoculation to Vero cells caused a discernible depletion of GFP expression at $24 \mathrm{~h}$ post-infection, while high levels of GFP expression was observed in virus-infected groups without melittin treatment, as disclosed through fluorescence microscopy. In comparison to virus-infected groups, a pronounced decline in viral titer of VSV-GFP $(1598$-fold, $P<0.01)$ was observed following a $30 \mathrm{~min}$ of exposure to melittin.
Moreover, VSV-GFP infectivity to HEK293T cells began to reduce after a 5 -min incubation with melittin $(2 \mu \mathrm{g} / \mathrm{mL})$ and continued to wane during 10,20, and $30 \mathrm{~min}$, indicating rapid virucidal kinetics of melittin [36].

Delivery of biochemical compounds by immunoliposomes encompassing complete or fragmented antibodies represents an optimistic strategy for coping with cancers and viral infections [80]. In an effort to construct and to evaluate antimicrobial peptide (AMP)-loaded immunoliposome system, Falco et al. incorporated melittin into immunoliposomes containing antibodies against glycoprotein $\mathrm{G}$ of fish viral hemorrhagic septicemia rhabdovirus (VHSV), a rhabdovirus infecting cold-blooded aquatic creatures [37]. At concentrations equivalent to 25 and $50 \mu \mathrm{M}$, both melittin-loaded liposomes and immunoliposomes were capable of inhibiting VHSVinfected cell foci formation in a dose- and time-dependent manner. For instance, inhibition rates of VHSV infectivity were $89.9 \%$ and $95.2 \%$ in the presence of melittin-loaded liposomes $(50 \mu \mathrm{M})$ and immunoliposomes $(50 \mu \mathrm{M})$, respectively. Both melittin-loaded liposomes and immunoliposomes interdicted the infectivity of VHSV after virus adsorption to fish cell line epithelioma papulosum cyprini (EPC) at time point 0 and $4 \mathrm{~h}$ post-infection [37]. In addition, EPC cell monolayers exhibited $>80 \%$ viability after a 24 -h exposure to melittin-loaded liposomes $(25 \mu \mathrm{M})$ and immunoliposomes $(50 \mu \mathrm{M})$ at $14^{\circ} \mathrm{C}$. These findings suggest that AMP-loaded immunoliposomes might have an enormous potential to prevent or treat viral infections as the configuration of their constituents (i.e., AMP type, antibody fragments, and/or phospholipid composition) can be optimized.

\section{Virgaviridae}

Virgaviridae is a family of plant-associated viruses with rod-shaped virions and single-stranded, positive-sense RNA genome [81]. As a typical member of Virgaviridae, tobacco mosaic virus (TMV) had a long and illustrious history since the late nineteenth century. The virus invades a wide spectrum of plants, in particular genera belonging to Solanaceae [82].

Amino acid sequences of melittin and coat protein of tobacco mosaic virus (TMV) at positions 71-94, which are known to be pivotal for protein-RNA and proteinprotein interactions, exhibit partial resemblance. Based on this similarity, an investigation was conducted by Marcos et al. to decipher whether melittin abrogates TMV infectivity and interacts with the viral particles and their RNA genomes [44]. Addition of melittin $(5 \mu \mathrm{M})$ into a solution containing TMV led to reduction $(10 \%)$ in number of necrotic local lesions on tobacco leaves compared to non-treated samples. As inferred from farultraviolet circular dichroism (CD) spectroscopy, melittin adopted a random coil and alpha-helical conformations in 
the absence and presence of TMV RNA, respectively. When combined with $5 \mu \mathrm{M}$ of melittin, TMV RNA showed not only a significant enhancement in electrophoretic mobility but also shifts in $\mathrm{CD}$ spectrum, suggesting RNA conformational changes are induced by melittin [44]. In general, these findings open up a range of new applications for melittin in the field of plant and agricultural virology.

\section{In vivo studies}

Apart from in vitro investigations, some empirical evidences exist with regard to anti-viral efficiency of melittin in animal models. For instance, co-incubation of melittin $(100 \mathrm{ng})$ with $5 \mathrm{MLD}_{50}$ (dose lethal to $50 \%$ of mice) of influenza A virus subtype H1N1 for $30 \mathrm{~min}$ and subsequent intranasal administration of the mixture resulted in $100 \%$ survivability of six-week-old C57BL/6 female mice up to 8 days post-infection (dpi), whereas all phosphatebuffered saline (PBS)/H1N1-treated mice displayed several respiratory disease symptoms and perished at $8 \mathrm{dpi}$. Unlike PBS/H1N1-treated mice, melittin/H1N1-treated mice were protected from body weight loss. Since melittin/H1N1-treated mice exhibited considerably lower lung viral titer in comparison to $\mathrm{PBS} / \mathrm{H} 1 \mathrm{~N} 1$ treated mice at $5 \mathrm{dpi}$, melittin rescued them from lethal infections of influenza A [36].

The effectiveness of melittin for the treatment of influenza-infected chicken embryos has been exemplified in a report by Michálek et al. [83]. In this regard, influenza A virus subtype H7N7 was inoculated into embryo's allantois of 9-day-old specific pathogen-free (SPF) embryonated chicken eggs and incubated for $24 \mathrm{~h}$, after which different concentrations of melittin was injected into allantoic fluid. Chicken embryos received only influenza A virus showed survival rates of $40 \%$, implicating high pathogenicity of the virus against embryos. By contrast, influenzainfected embryos which were inoculated with melittin $(0.05,0.5$, and $1 \mu \mathrm{M})$ exhibited $80 \%$ viability. However, higher concentrations of melittin $(2$ and $4 \mu \mathrm{M})$ were toxic for influenza-infected embryos, resulting in survival rates of $40 \%$. These experimental data suggest that melittin is well tolerated by chicken embryos for up to $1 \mu \mathrm{M}$ [83]. On the whole, melittin holds promise for a new avenue of antiinfluenza therapy, from medicine to husbandry.

A prospective, placebo-controlled double-blinded trial was conducted to evaluate the effects of subcutaneously administrated melittin $(500 \mu \mathrm{g}$ per $\mathrm{kg}$ body weight $)$ on the general health status of feline immunodeficiency virus (FIV)-infected cats and the severity of clinical symptoms during a 6-week treatment period [84]. In contrast to the placebo group receiving PBS, treatment with melittin led to a constant improvement in cats' general health status, expressed as Karnofsky's score. Statistically, a significant difference $(P=0.015)$ in improvement of conjunctivitis was observed between melittin-treated and placebotreated cats. Although both groups exhibited amelioration of stomatitis, however, this was not significant. Moreover, no adverse effects including hemolysis and irritation at the injection site in FIV-infected cats were noted [84]. In the case of laboratory parameters (e.g., packed cell volume, hemoglobin, and white blood cells), there were no statistically significant differences between both groups. As for immunologic parameters including $\mathrm{CD}^{+}$lymphocytes, $\mathrm{CD}^{+}{ }^{+}$lymphocytes, and $\mathrm{CD} 4 / \mathrm{CD} 8$ ratio, no significant differences between both groups were evident. Similar results were also observed with regard to surrogate parameters (biopterin and 7-xanthopterin in serum and urine) in both groups. Authors stated that lack of significant changes could be attributable to various reasons including inability of melittin to yield strong anti-viral activity in vivo, administration of low dosage of melittin, long treatment intervals, short length of treatment period, and development of antibodies against melittin [84]. Overall, assessment of changes in FIV load together with increasing the total number of cats should be considered for future investigations to provide more trustworthy statistical findings.

\section{Plausible anti-viral mechanisms}

A better understanding of anti-microbial mechanisms of melittin will definitely help us to optimize anti-viral strategies. Many AMPs act primarily through membrane disruption [85]. In this context, direct interaction of melittin with viral envelopes or capsid proteins interferes with binding or uptake of viruses by cells $[34,42,43]$. Besides, other plausible anti-viral mechanisms of action such as impediment of viral multiplication [36], decreasing expression levels of viral mRNAs [36, 42], inducing conformational changes in viral genome [44], deactivation of viral packaging [43], attenuation of viral cytopathic effects [36], and inhibition of viral-induced cell fusion [34] have been documented in the literature, as depicted in Fig. 1.

\section{Future prospects}

As hinted above, melittin exerts broad spectrum of anti-viral activities, albeit being relatively cytotoxic at higher doses. Multiple approaches can be propounded to diminish cytotoxicity of melittin while augmenting its anti-viral effects, thereby heightening therapeutic indices of the peptide. In this regard, targeted in vivo delivery of AMPs like melittin through a 


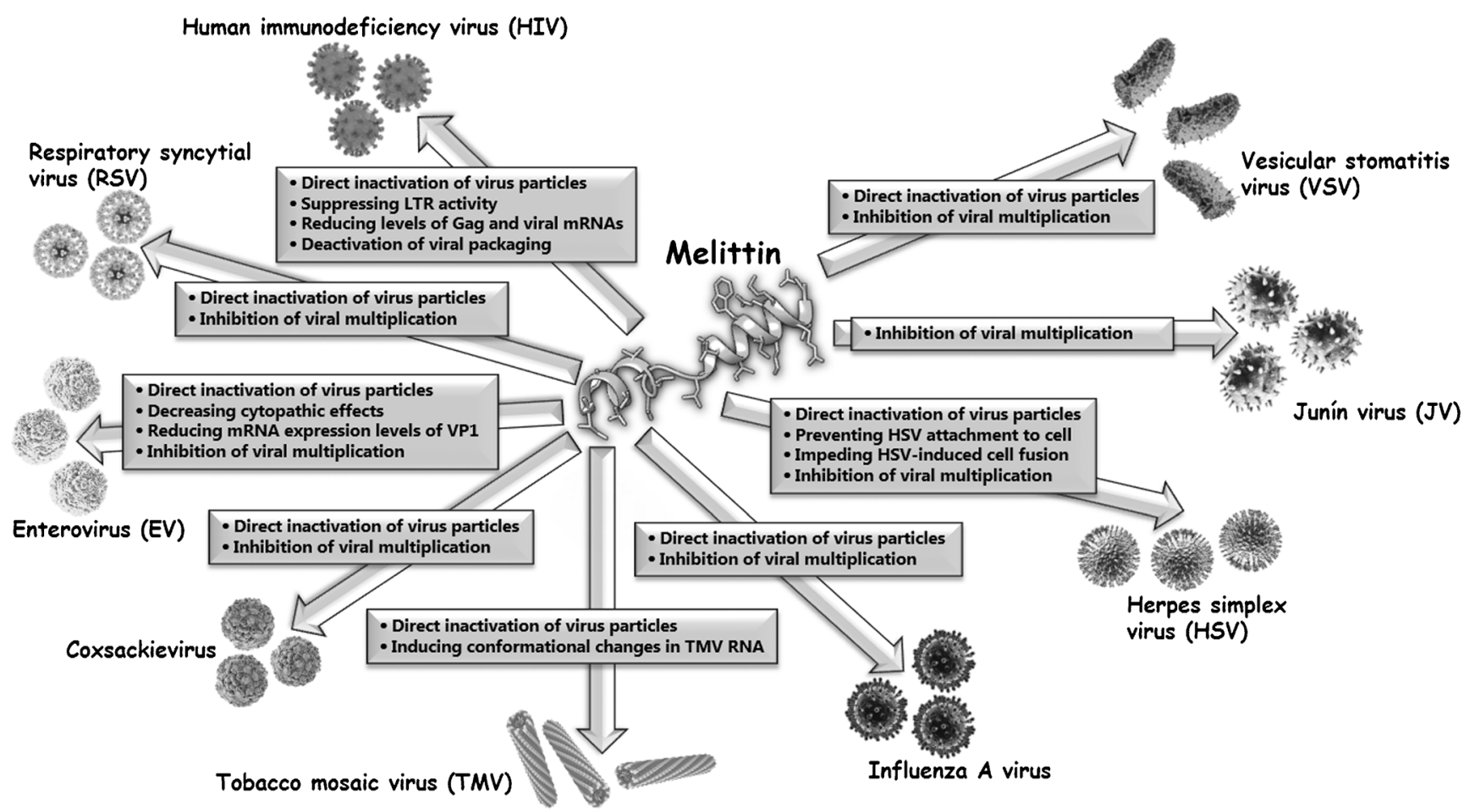

Fig. 1 Possible inhibitory mechanisms of melittin toward different viruses

nanocarrier exemplifies a safe solution with desirable pharmacokinetics for both anti-viral and anti-cancer therapies [86, 87]. An alternate novel enticing strategy is conjugation of melittin with aptamers, which are oligonucleotide or peptide molecules capable of binding to their targets with high affinity and specificity [88]. Designing hydrogels embedded with melittin for topical treatment of herpes blisters and papilloma virus-related warts is the other practicable approach which has not been reported hitherto. Last but not least, combination of melittin and current anti-viral drugs may reduce both concerns associated with cytotoxicity of melittin and probability of developing drug-resistant viruses.

\section{Conclusions}

Several decades of endeavor have allowed researchers to partially disclose anti-viral effects of melittin against both RNA and DNA viruses that fall within diverse viral families. However, tangible challenges such as medication safety lie ahead in the path toward clinical application of melittin as an anti-viral drug. As a consequence, future investigations may need to focus on deciphering mechanisms behind the anti-viral activity of melittin, examining various routes of administrations, and scrutinizing the effectiveness of melittin in primate models to retrieve additional pre-clinical data. Undoubtedly, anti-infective properties of melittin will provide new avenues in all fields of clinical researches, particularly medical virology.
Author contributions All authors contributed equally to writing and revision of the manuscript. The authors reviewed and approved the final submitted manuscript.

\section{Compliance with ethical standards}

Conflict of interest The authors declare that they have no conflicts of interest.

\section{References}

1. Howard CR, Fletcher NF (2012) Emerging virus diseases: can we ever expect the unexpected? Emerg Microbes Infect 1(12):e46. https://doi.org/10.1038/emi.2012.47

2. Taubenberger JK, Morens DM (2006) 1918 Influenza: the mother of all pandemics. Emerg Infect Dis 12(1):15-22. https://doi.org/10. 3201/eid1201.050979

3. World Health Organization (WHO). HIV/AIDS: data and statistics. https://www.who.int/hiv/data/en/. Accessed 19 March 2019

4. Saxena SK, Mishra N, Saxena R (2009) Advances in antiviral drug discovery and development: part II: advancements in antiviral drug development. Futur Virol 4(3):209-215. https://doi.org/10.2217/ fvl.09.1

5. Petersen H, Mostafa A, Tantawy MA, Iqbal AA, Hoffmann D, Tallam A, Selvakumar B, Pessler F, Beer M, Rautenschlein S, Pleschka S (2018) NS Segment of a 1918 Influenza A virusdescendent enhances replication of H1N1pdm09 and virusinduced cellular immune response in mammalian and avian systems. Front Microbiol 9:526. https://doi.org/10.3389/fmicb.2018. 00526

6. Memariani H, Shahbazzadeh D, Ranjbar R, Behdani M, Memariani M, Pooshang Bagheri K (2017) Design and characterization of short hybrid antimicrobial peptides from pEM-2, mastoparan- 
VT1, and mastoparan-B. Chem Biol Drug Des 89(3):327-338. https://doi.org/10.1111/cbdd.12864

7. Memariani H, Memariani M, Pourmand MR (2018) Venomderived peptide Mastoparan-1 eradicates planktonic and biofilmembedded methicillin-resistant Staphylococcus aureus isolates. Microb Pathog 119:72-80. https://doi.org/10.1016/j.micpath. 2018.04.008

8. Andreotti N, Jouirou B, Mouhat S, Mouhat L, Sabatier J (2010) Therapeutic value of peptides from animal venoms. In: Mandler L, Liu HW (eds) Comprehensive natural products II. Elsevier, Oxford

9. Pennington MW, Czerwinski A, Norton RS (2018) Peptide therapeutics from venom: current status and potential. Bioorg Med Chem 26(10):2738-2758. https://doi.org/10.1016/j.bmc. 2017.09.029

10. Memariani H, Shahbazzadeh D, Sabatier JM, Memariani M, Karbalaeimahdi A, Bagheri KP (2016) Mechanism of action and in vitro activity of short hybrid antimicrobial peptide PV3 against Pseudomonas aeruginosa. Biochem Biophys Res Commun 479(1):103-108. https://doi.org/10.1016/j.bbrc.2016.09.045

11. Cushman DW, Ondetti MA (1999) Design of angiotensin converting enzyme inhibitors. Nat Med 5(10):1110-1113. https:// doi.org/10.1038/13423

12. O'Shea JC, Tcheng JE (2002) Eptifibatide: a potent inhibitor of the platelet receptor integrin glycoprotein IIb/IIIa. Expert Opin Pharmacother 3(8):1199-1210. https://doi.org/10.1517/14656566. 3.8.1199

13. Gladwell TD (2002) Bivalirudin: a direct thrombin inhibitor. Clin Ther 24(1):38-58. https://doi.org/10.1016/S01492918(02)85004-4

14. Miljanich GP (2004) Ziconotide: neuronal calcium channel blocker for treating severe chronic pain. Curr Med Chem 11(23):30293040. https://doi.org/10.2174/0929867043363884

15. Menozzi A, Merlini PA, Ardissino D (2005) Tirofiban in acute coronary syndromes. Expert Rev Cardiovasc Ther 3(2):193-206. https://doi.org/10.1586/14779072.3.2.193

16. Furman BL (2012) The development of Byetta (exenatide) from the venom of the Gila monster as an anti-diabetic agent. Toxicon 59(4): 464-471. https://doi.org/10.1016/j.toxicon.2010.12.016

17. Robinson SD, Undheim EAB, Ueberheide B, King GF (2017) Venom peptides as therapeutics: advances, challenges and the future of venom-peptide discovery. Expert Rev Proteomics 14(10): 931-939. https://doi.org/10.1080/14789450.2017.1377613

18. Habermann E (1972) Bee and wasp venoms. Science 177(4046): 314-322. https://doi.org/10.1126/science.177.4046.314

19. Dempsey CE (1990) The actions of melittin on membranes. Biochim Biophys Acta 1031(2):143-161. https://doi.org/10.1016/ 0304-4157(90)90006-X

20. Matsuzaki K, Yoneyama S, Miyajima K (1997) Pore formation and translocation of melittin. Biophys J 73(2):831-838. https://doi.org/ 10.1016/S0006-3495(97)78115-3

21. Raghuraman H, Chattopadhyay A (2007) Melittin: a membraneactive peptide with diverse functions. Biosci Rep 27(4-5):189223. https://doi.org/10.1007/s10540-006-9030-z

22. Terwilliger TC, Eisenberg D (1982) The structure of melittin. II Interpretation of the structure. J Biol Chem 257(11):6016-6022

23. Bello J, Bello HR, Granados E (1982) Conformation and aggregation of melittin: dependence on $\mathrm{pH}$ and concentration. Biochemistry 21(3):461-465. https://doi.org/10.1021/bi00532a007

24. Picoli T, Peter CM, Zani JL, Waller SB, Lopes MG, Boesche KN, Vargas GDA, Hubner SO, Fischer G (2017) Melittin and its potential in the destruction and inhibition of the biofilm formation by Staphylococcus aureus, Escherichia coli and Pseudomonas aeruginosa isolated from bovine milk. Microb Pathog 112:57-62. https://doi.org/10.1016/j.micpath.2017.09.046
25. van den Bogaart G, Guzman JV, Mika JT, Poolman B (2008) On the mechanism of pore formation by melittin. J Biol Chem 283(49): 33854-33857. https://doi.org/10.1074/jbc.M805171200

26. Lee MT, Sun TL, Hung WC, Huang HW (2013) Process of inducing pores in membranes by melittin. Proc Natl Acad Sci U S A 110(35):14243-14248. https://doi.org/10.1073/pnas.1307010110

27. Gajski G, Garaj-Vrhovac V (2013) Melittin: a lytic peptide with anticancer properties. Environ Toxicol Pharmacol 36(2):697-705. https://doi.org/10.1016/j.etap.2013.06.009

28. Lee G, Bae H (2016) Anti-inflammatory applications of melittin, a major component of bee venom: detailed mechanism of action and adverse effects. Molecules 21(5). https://doi.org/10.3390/ molecules 21050616

29. Hossen S, Gan SH, Khalil I (2017) Melittin, a potential natural toxin of crude bee venom: probable future arsenal in the treatment of diabetes mellitus. J Chem 2017:1-7. https://doi.org/10.1155/2017/ 4035626

30. Memariani H, Memariani M, Shahidi-Dadras M, Nasiri S, Akhavan MM, Moravvej H (2019) Melittin: from honeybees to superbugs. Appl Microbiol Biotechnol 103(8):3265-3276. https://doi.org/10. 1007/s00253-019-09698-y

31. Bramwell VW, Somavarapu S, Outschoorn I, Alpar HO (2003) Adjuvant action of melittin following intranasal immunisation with tetanus and diphtheria toxoids. J Drug Target 11(8-10):525-530. https://doi.org/10.1080/10611860410001670080

32. Albiol Matanic VC, Castilla V (2004) Antiviral activity of antimicrobial cationic peptides against Junin virus and herpes simplex virus. Int J Antimicrob Agents 23(4):382-389. https://doi.org/10. 1016/j.ijantimicag.2003.07.022

33. Picoli T, Peter CM, Vargas GD, Hübner SO, de Lima M, Fischer G (2018) Antiviral and virucidal potential of melittin and apamin against bovine herpesvirus type 1 and bovine viral diarrhea virus. Pesq Vet Bras 38(4):595-604. https://doi.org/10.1590/1678-5150pvb-4758

34. Baghian A, Kousoulas KG (1993) Role of the $\mathrm{Na}^{+}, \mathrm{K}^{+}$pump in herpes simplex type 1-induced cell fusion: melittin causes specific reversion of syncytial mutants with the syn 1 mutation to $\mathrm{syn}^{+}$(wildtype) phenotype. Virology 196(2):548-556. https://doi.org/10. 1006/viro.1993.1510

35. Yasin B, Pang M, Turner JS, Cho Y, Dinh NN, Waring AJ, Lehrer RI, Wagar EA (2000) Evaluation of the inactivation of infectious Herpes simplex virus by host-defense peptides. Eur J Clin Microbiol Infect Dis 19(3):187-194. https://doi.org/10.1007/ s100960050457

36. Uddin MB, Lee BH, Nikapitiya C, Kim JH, Kim TH, Lee HC, Kim CG, Lee JS, Kim CJ (2016) Inhibitory effects of bee venom and its components against viruses in vitro and in vivo. J Microbiol 54(12): 853-866. https://doi.org/10.1007/s12275-016-6376-1

37. Falco A, Barrajon-Catalan E, Menendez-Gutierrez MP, Coll J, Micol V, Estepa A (2013) Melittin-loaded immunoliposomes against viral surface proteins, a new approach to antiviral therapy. Antivir Res 97(2):218-221. https://doi.org/10.1016/j.antiviral. 2012.12.004

38. Esser AF, Bartholomew RM, Jensen FC, Muller-Eberhard HJ (1979) Disassembly of viral membranes by complement independent of channel formation. Proc Natl Acad Sci U S A 76(11):58435847. https://doi.org/10.1073/pnas.76.11.5843

39. Boone LR, Skalka A (1980) Two species of full-length cDNA are synthesized in high yield by melittin-treated avian retrovirus particles. Proc Natl Acad Sci U S A 77(2):847-851. https://doi.org/10. 1073/pnas.77.2.847

40. Yong WH, Wyman S, Levy JA (1990) Optimal conditions for synthesizing complementary DNA in the HIV-1 endogenous reverse transcriptase reaction. AIDS 4(3):199-206

41. Wachinger M, Saermark T, Erfle V (1992) Influence of amphipathic peptides on the HIV-1 production in persistently infected $\mathrm{T}$ 
lymphoma cells. FEBS Lett 309(3):235-241. https://doi.org/10. 1016/0014-5793(92)80780-K

42. Wachinger M, Kleinschmidt A, Winder D, von Pechmann N, Ludvigsen A, Neumann M, Holle R, Salmons B, Erfle V, BrackWerner R (1998) Antimicrobial peptides melittin and cecropin inhibit replication of human immunodeficiency virus 1 by suppressing viral gene expression. J Gen Virol 79(Pt 4):731-740. https://doi. org/10.1099/0022-1317-79-4-731

43. Hood JL, Jallouk AP, Campbell N, Ratner L, Wickline SA (2013) Cytolytic nanoparticles attenuate HIV-1 infectivity. Antivir Ther 18(1):95-103. https://doi.org/10.3851/IMP2346

44. Marcos JF, Beachy RN, Houghten RA, Blondelle SE, Perez-Paya E (1995) Inhibition of a plant virus infection by analogs of melittin. Proc Natl Acad Sci U S A 92(26):12466-12469. https://doi.org/10. 1073/pnas.92.26.12466

45. Paweska JT (2014) Lujo virus hemorrhagic feverl. In: Ergonul O, Can F, Akova M, Madoff L (eds) Emerging infectious diseases: clinical case studies, 1st edn. Academic Press, Elsevier Inc., London. https://doi.org/10.1016/B978-0-12-416975-3.00007-8

46. King AMQ, Adams MJ, Carstens EB, Lefkowitz E (2012) Virus taxonomy: ninth report of the international committee on taxonomy of viruses. Academic Press, Elsevier Inc., San Diego

47. Hallam SJ, Koma T, Maruyama J, Paessler S (2018) Review of Mammarenavirus biology and replication. Front Microbiol 9: 1751. https://doi.org/10.3389/fmicb.2018.01751

48. Moraz ML, Kunz S (2011) Pathogenesis of arenavirus hemorrhagic fevers. Expert Rev Anti-Infect Ther 9(1):49-59. https://doi.org/10. 1586/eri. 10.142

49. Gowen BB, Juelich TL, Sefing EJ, Brasel T, Smith JK, Zhang L, Tigabu B, Hill TE, Yun T, Pietzsch C, Furuta Y, Freiberg AN (2013) Favipiravir (T-705) inhibits Junin virus infection and reduces mortality in a guinea pig model of Argentine hemorrhagic fever. PLoS Negl Trop Dis 7(12):e2614. https://doi.org/10.1371/journal.pntd. 0002614

50. Enria DA, Briggiler AM, Sanchez Z (2008) Treatment of Argentine hemorrhagic fever. Antivir Res 78(1):132-139. https://doi.org/10. 1016/j.antiviral.2007.10.010

51. Grant A, Seregin A, Huang C, Kolokoltsova O, Brasier A, Peters C, Paessler S (2012) Junin virus pathogenesis and virus replication. Viruses 4(10):2317-2339. https://doi.org/10.3390/v4102317

52. Simmonds P, Becher P, Bukh J, Gould EA, Meyers G, Monath T, Muerhoff S, Pletnev A, Rico-Hesse R, Smith DB, Stapleton JT, Ictv Report C (2017) ICTV virus taxonomy profile: Flaviviridae. J Gen Virol 98(1):2-3. https://doi.org/10.1099/jgv.0.000672

53. Neufeldt CJ, Cortese M, Acosta EG, Bartenschlager R (2018) Rewiring cellular networks by members of the Flaviviridae family. Nat Rev Microbiol 16(3):125-142. https://doi.org/10.1038/ nrmicro.2017.170

54. Scharnböck B, Roch FF, Richter V, Funke C, Firth CL, Obritzhauser W, Baumgartner W, Kasbohrer A, Pinior B (2018) A meta-analysis of bovine viral diarrhoea virus (BVDV) prevalences in the global cattle population. Sci Rep 8(1):14420. https:// doi.org/10.1038/s41598-018-32831-2

55. Whitley RJ, Roizman B (2001) Herpes simplex virus infections. Lancet 357(9267):1513-1518. https://doi.org/10.1016/S01406736(00)04638-9

56. Roizman B, Knipe DM, Whitley RJ (2013) Herpes simplex viruses. In: Knipe DM, Howley PM, Cohen JI et al (eds) Fields virology, 6th edn. Lippincott-Williams \&Wilkins, Philadelphia

57. Sharma V, Mobeen F, Prakash T (2016) Comparative genomics of Herpesviridae family to look for potential signatures of human infecting strains. Int J Genomics 2016, 9543274. https://doi.org/ $10.1155 / 2016 / 9543274$

58. Morrison LA (2004) The Toll of herpes simplex virus infection. Trends Microbiol 12(8):353-356. https://doi.org/10.1016/j.tim. 2004.06.001
59. Birkmann A, Zimmermann H (2016) HSV antivirals - current and future treatment options. Curr Opin Virol 18:9-13. https://doi.org/ 10.1016/j.coviro.2016.01.013

60. Silverman JL, Heldwein EE (2013) Mutations in the cytoplasmic tail of herpes simplex virus $1 \mathrm{gH}$ reduce the fusogenicity of $\mathrm{gB}$ in transfected cells. J Virol 87(18):10139-10147. https://doi.org/10. 1128/JVI.01760-13

61. Baghian A, Jaynes J, Enright F, Kousoulas KG (1997) An amphipathic alpha-helical synthetic peptide analogue of melittin inhibits herpes simplex virus-1 (HSV-1)-induced cell fusion and virus spread. Peptides 18(2):177-183. https://doi.org/10.1016/S01969781(96)00290-2

62. Kousoulas KG, Bzik DJ, Person S (1983) Effect of the ionophore monensin on herpes simplex virus type 1-induced cell fusion, glycoprotein synthesis, and virion infectivity. Intervirology 20(1):5660. https://doi.org/10.1159/000149375

63. Cuppoletti J, Abbott AJ (1990) Interaction of melittin with the $\left(\mathrm{Na}^{+}\right.$ $+\mathrm{K}^{+}$) ATPase: evidence for a melittin-induced conformational change. Arch Biochem Biophys 283(2):249-257. https://doi.org/ 10.1016/0003-9861(90)90639-G

64. Perez DR, Angel M, Gonzalez-Reiche AS, Santos J, Obadan A, Martinez-Sobrido L (2017) Plasmid-based reverse genetics of influenza A virus. In: Perez DR (ed) Reverse genetics of RNA: methods and protocols, methods in molecular biology, vol 1602, 1st edn. Humana Press Inc, New York, pp 251-273. https://doi.org/ 10.1007/978-1-4939-6964-7

65. Maclachlan NJ, Dubovi EJ (2017) Fenner's veterinary virology, 5th edn. Academic Press, Elsevier Inc., Cambridge

66. World Health Organization (WHO). Influenza: Burden of disease. https://www.who.int/influenza/surveillance_monitoring/bod/en/. Accessed 15 Dec 2018

67. van Doorn HR, Yu H (2013) Viral respiratory infections. In: Magill AJ, Ryan ET, Hill DR, Solomon T (eds) Hunter's tropical medicine and emerging infectious diseases, 9th edn. Saunders, New York. https://doi.org/10.1016/B978-1-4160-4390-4.00029-1

68. Li Q, Zhao Z, Zhou D, Chen Y, Hong W, Cao L, Yang J, Zhang Y, Shi W, Cao Z, Wu Y, Yan H, Li W (2011) Virucidal activity of a scorpion venom peptide variant mucroporin-M1 against measles, SARS-CoV and influenza H5N1 viruses. Peptides 32(7):1518 1525. https://doi.org/10.1016/j.peptides.2011.05.015

69. Zell R (2018) Picornaviridae-the ever-growing virus family. Arch Virol 163(2):299-317. https://doi.org/10.1007/s00705-017-3614-8

70. Cox JA, Hiscox JA, Solomon T, Ooi MH, Ng LFP (2017) Immunopathogenesis and virus-host interactions of Enterovirus 71 in patients with hand, foot and mouth disease. Front Microbiol 8:2249. https://doi.org/10.3389/fmicb. 2017.02249

71. Afonso CL, Amarasinghe GK, Banyai K, Bao Y, Basler CF, Bavari S, Bejerman N, Blasdell KR, Briand FX, Briese T, Bukreyev A, Calisher $\mathrm{CH}$, Chandran K, Cheng J, Clawson AN, Collins PL, Dietzgen RG, Dolnik O, Domier LL, Durrwald R, Dye JM, Easton AJ, Ebihara H, Farkas SL, Freitas-Astua J, Formenty P, Fouchier RA, Fu Y, Ghedin E, Goodin MM, Hewson R, Horie M, Hyndman TH, Jiang D, Kitajima EW, Kobinger GP, Kondo H, Kurath G, Lamb RA, Lenardon S, Leroy EM, Li CX, Lin XD, Liu L, Longdon B, Marton S, Maisner A, Muhlberger E, Netesov SV, Nowotny N, Patterson JL, Payne SL, Paweska JT, Randall RE, Rima BK, Rota P, Rubbenstroth D, Schwemmle M, Shi M, Smither SJ, Stenglein MD, Stone DM, Takada A, Terregino C, Tesh RB, Tian JH, Tomonaga K, Tordo N, Towner JS, Vasilakis N, Verbeek M, Volchkov VE, Wahl-Jensen V, Walsh JA, Walker PJ, Wang D, Wang LF, Wetzel T, Whitfield AE, Xie JT, Yuen KY, Zhang YZ, Kuhn JH (2016) Taxonomy of the order Mononegavirales: update 2016. Arch Virol 161(8):2351-2360. https://doi.org/10.1007/ s00705-016-2880-1 
72. Walsh EE (2017) Respiratory syncytial virus infection: an illness for all ages. Clin Chest Med 38(1):29-36. https://doi.org/10.1016/j. ccm.2016.11.010

73. Nair H, Nokes DJ, Gessner BD, Dherani M, Madhi SA, Singleton RJ, O'Brien KL, Roca A, Wright PF, Bruce N, Chandran A, Theodoratou E, Sutanto A, Sedyaningsih ER, Ngama M, Munywoki PK, Kartasasmita C, Simoes EA, Rudan I, Weber MW, Campbell H (2010) Global burden of acute lower respiratory infections due to respiratory syncytial virus in young children: a systematic review and meta-analysis. Lancet 375(9725):15451555. https://doi.org/10.1016/S0140-6736(10)60206-1

74. Kestler M, Munoz P, Mateos M, Adrados D, Bouza E (2018) Respiratory syncytial virus burden among adults during flu season: an underestimated pathology. J Hosp Infect 100(4):463-468. https://doi.org/10.1016/j.jhin.2018.03.034

75. Turner TL, Kopp BT, Paul G, Landgrave LC, Hayes D Jr, Thompson R (2014) Respiratory syncytial virus: current and emerging treatment options. Clinicoecon Outcomes Res 6:217225. https://doi.org/10.2147/CEOR.S60710

76. Hobson JJ, Al-Khouja A, Curley P, Meyers D, Flexner C, Siccardi M, Owen A, Meyers CF, Rannard SP (2019) Semi-solid prodrug nanoparticles for long-acting delivery of water-soluble antiretroviral drugs within combination HIV therapies. Nat Commun 10(1): 1413. https://doi.org/10.1038/s41467-019-09354-z

77. Sarzotti-Kelsoe M, Bailer RT, Turk E, Lin CL, Bilska M, Greene KM, Gao H, Todd CA, Ozaki DA, Seaman MS, Mascola JR, Montefiori DC (2014) Optimization and validation of the TZM-bl assay for standardized assessments of neutralizing antibodies against HIV-1. J Immunol Methods 409:131-146. https://doi.org/ 10.1016/j.jim.2013.11.022

78. Lichty BD, Power AT, Stojdl DF, Bell JC (2004) Vesicular stomatitis virus: re-inventing the bullet. Trends Mol Med 10(5):210-216. https://doi.org/10.1016/j.molmed.2004.03.003

79. Strauss EG, Strauss JH (2008) Viruses and human disease, 2nd edn. Academic Press, San Diego

80. Paszko E, Senge MO (2012) Immunoliposomes. Curr Med Chem 19(31):5239-5277. https://doi.org/10.2174/092986712803833362
81. Adams MJ, Adkins S, Bragard C, Gilmer D, Li D, MacFarlane SA, Wong SM, Melcher U, Ratti C, Ryu KH, Ictv Report C (2017) ICTV virus taxonomy profile: Virgaviridae. J Gen Virol 98(8): 1999-2000. https://doi.org/10.1099/jgv.0.000884

82. Yamaya J, Yoshioka M, Meshi T, Okada Y, Ohno T (1988) Expression of tobacco mosaic virus RNA in transgenic plants. Mol Gen Genet 211(3):520-525. https://doi.org/10.1007/ BF00425710

83. Michálek P, Zítka O, Guráň R, Milosavljevič V, Kopel P, Adam V, Hegar Z (2015) Effect of melittin on influenza-infected chicken embryos. MENDELNET 475-479

84. Hartmann AD, Wilhelm N, Erfle V, Hartmann K (2016) Clinical efficacy of melittin in the treatment of cats infected with the feline immunodeficiency virus. Tierarztl Prax Ausg K Kleintiere Heimtiere 44(6):417-423. https://doi.org/10.15654/TPK-150890

85. Bahar AA, Ren D (2013) Antimicrobial peptides. Pharmaceuticals (Basel) 6(12):1543-1575. https://doi.org/10.3390/ph6121543

86. Lauster D, Glanz M, Bardua M, Ludwig K, Hellmund M, Hoffmann U, Hamann A, Bottcher C, Haag R, Hackenberger CPR, Herrmann A (2017) Multivalent peptide-nanoparticle conjugates for influenza-virus inhibition. Angew Chem Int Ed Engl 56(21):5931-5936. https://doi.org/10.1002/anie.201702005

87. Soman NR, Baldwin SL, Hu G, Marsh JN, Lanza GM, Heuser JE, Arbeit JM, Wickline SA, Schlesinger PH (2009) Molecularly targeted nanocarriers deliver the cytolytic peptide melittin specifically to tumor cells in mice, reducing tumor growth. J Clin Invest 119(9):2830-2842. https://doi.org/10.1172/JCI38842

88. Rajabnejad SH, Mokhtarzadeh A, Abnous K, Taghdisi SM, Ramezani M, Razavi BM (2018) Targeted delivery of melittin to cancer cells by AS1411 anti-nucleolin aptamer. Drug Dev Ind Pharm 44(6):982-987. https://doi.org/10.1080/03639045.2018. 1427760

Publisher's note Springer Nature remains neutral with regard to jurisdictional claims in published maps and institutional affiliations. 